\section{Effects of phthalates on the biology of the mussel Mytilus galloprovincialis (from the Atlantic Coast of El Jadida, Morocco)}

\author{
J. Sif, A. Khalil, H. Abouinan, A. Rouhi, \\ K. Mokhliss
}

Equipe de recherche Physiologie et Écotoxicologue, Laboratoire de Biologie, Faculté des Sciences, Université Chouïab Doukkali, El Jadida, Morocco

\section{Introduction}

Phthalates are found in many consumer products (can coating, shampoos, food containers, etc.). Di-2-ethylhexyl phthalate (DEHP) is widely used in the medical field. ${ }^{1}$ DEHP represents about $50 \%$ of the 18 esters marketed as phthalates. DEHP and n-dibutyl phthalate (DBP) are the most frequent components found in collected environmental samples. $^{2}$ There are little scientific data about phthalates in marine animals, including bivalves. These organisms are used to estimate the quality of coastal ecosystems in several biomonitoring programs. In the Moroccan Atlantic area of El Jadida, the bioaccumulation of metals and induction of metallothionein was revealed by several authors..$^{3-5}$ This research is an important component for our research team, to assess the health of the El Jadida coastal region. Our aim is to estimate the effect of potassium hydrogen phthalate (KHP) on growth, mortality and degree of filling of the mussel Mytilus galloprovincialis.

\section{Materials and Methods}

The mussels of the species M. galloprovincialis were collected during low tide at the wild mussel cluster of beach of El Jadida. They were stored in the laboratory in containing continuously oxygenated seawater $(n=50)$, with acclimatization periods of $36 \mathrm{~h}$. For this experiment, sizes of 1,2 and $3 \mathrm{~cm}$ were chosen for the mussels, and the contamination doses for the potassium hydrogen phthalate [ $\mathrm{C} 8 \mathrm{H} 5 \mathrm{KO} 4$ (KHP)] were of $250 \mathrm{mg}$ and $500 \mathrm{mg} / \mathrm{kg}$ of mussel for the first treatment period ( 2 and $4 \mathrm{mg} / \mathrm{L}$ for small; 20 and $40 \mathrm{mg} / \mathrm{L}$ for medium; 50 and $100 \mathrm{mg} / \mathrm{L}$ for large size mussels); and of 750 $\mathrm{mg}$ and $1000 \mathrm{mg} / \mathrm{kg}$ for the second treatment period ( 6 and $8 \mathrm{mg} / \mathrm{L}$ for small; 60 and $80 \mathrm{mg} / \mathrm{L}$ for medium; 150 and $200 \mathrm{mg} / \mathrm{L}$ for large size mussels). Each treatment period was 3-week long. The seawater (2 L/animal groups) is changed each day for theses animals. Control animals (three sizes) were set in the same conditions but without any contamination. Mortality, growth and condition index were the parameters studied in all groups (experimental and control): i) the mortality rate was assessed by inventorying deceased animals every $24 \mathrm{~h}$, for 6 weeks. It is expressed in percentage (\%). Dead animals were removed; ii) the study of the growth levels is based on the measurement of the length of the shell of the contaminated mussels; once a week during the six weeks of exposure to the KHP; using calipers. Five individual mussels were randomly selected from each tray for this purpose; iii) the condition index is a biometric index that reflects the degree of filling of the mussel shell. It is calculated through the following formula (AFNOR index):

$$
\begin{aligned}
\mathrm{CI}= & \text { (soft tissue weight } / \\
& \text { total weight) } \mathrm{X} 100 .
\end{aligned}
$$

The analysis of variance (ANOVA) and Student's $t$ test were used to assess the results (TGV Biosta software).

\section{Results and Discussion}

\section{Mortality study}

Following the contamination of the mussels at $250 \mathrm{mg} / \mathrm{kg}$ and $500 \mathrm{mg} / \mathrm{kg}$ of KHP, for small and medium-size individuals (respectively 1 and $2 \mathrm{~cm}$ ), we did not observe any deaths during the first three weeks. The mortality rate reached a maximum of $10 \%$ for small mussels on the $5^{\text {th }}$ week. The $3 \mathrm{~cm}$ mussels represented $7 \%$ of the mortality during the $3^{\text {rd }}$ week period, versus $2 \%$ in the control group. During the $2^{\text {nd }}$ stage when the KHP doses were increased, the mortality rate increased significantly to $14 \%$ at 6 weeks of exposure at 750 $\mathrm{mg} / \mathrm{kg}$ of KHP and to $21 \%$ on the $5^{\text {th }}$ week of exposure at the $1000 \mathrm{mg} / \mathrm{kg}$ levels.

\section{Study of the growth}

The first result to note is the KHP negative effect on the growth of $M$. galloprovincialis. This effect is more significant for large mussels $(3 \mathrm{~cm})$ that were exposed to 750 and 1000 $\mathrm{mg} / \mathrm{kg}$ of KHP (Figure 1).

\section{Study of the condition index}

A slight difference in condition index (CI) is noticed between mussels exposed to KHP and the control groups. The highest and signif-
Correspondence: Jamila Sif, Equipe de recherche Physiologie et Écotoxicologue, Laboratoire de Biologie, Faculté des Sciences, Université Chouïab Doukkali, El Jadida, Morocco.

E-mail: sif.jamila16@yahoo.com

Key words: Mytilus galloprovincialis; phthalates; biology.

Conference presentation: part of this paper was presented at ECOBIM meeting, 2016 May-June, Le Havre, France.

This work is licensed under a Creative Commons Attribution NonCommercial 4.0 License (CC BYNC 4.0).

○Copyright J. Sif et al., 2016

Licensee PAGEPress, Italy

Journal of Xenobiotics 2016; 6:6589

doi:10.4081/xeno.2016.6589

icant value was 17.54 recorded in control animals versus 15.66 for those of $3 \mathrm{~cm}$ in size exposed to $500 \mathrm{mg} / \mathrm{kg}$ of KHP (first treatment period). The other significant difference of the $\mathrm{CI}$ is noticed in mussel of the same size are 13.86 of control versus 12.86 and 12.30 exposed to 750 and $1000 \mathrm{mg} / \mathrm{kg}$ of phthalate respectively (second treatment period).

\section{Conclusions}

In the light of the results, we can conclude that the mussel $M$. galloprovincialis can survive high levels of phthalate exposure, at least, during the 6 weeks. Disturbances are notably found on the growth rate across the length of the shell and its degree of filling. According to data from the literature, the phthalate DEHP in rats has a very low acute toxicity as the lethal dose required to reach 50\% mortality (LD 50) is greater than $25 \mathrm{~g} / \mathrm{kg}$ when administered orally and $200 \mathrm{mg} / \mathrm{kg}$ when administered by parenteral way. As well, the observed effect is mostly physiological. In fact, after administration to rabbits, by forced feeding, increasing doses of di-n-butyl phthalate at 250, 500, 750 $\mathrm{mg} / \mathrm{kg} /$ day for 4 weeks, had no impact on mortality, but blood-toxic, hepatotoxic, reprotoxic effects together with effects on kidneys were observed. ${ }^{6,7}$ Genital malformations were also observed in male rats under the influence of phtalates. ${ }^{8}$ This study should be supplemented by the extraction of phthalates (via Soxhlet) and phthalate detection achieved by gas chromatography or mass spectrometry. Subsequently a physiology disturbance study should be conducted. ${ }^{9}$ 

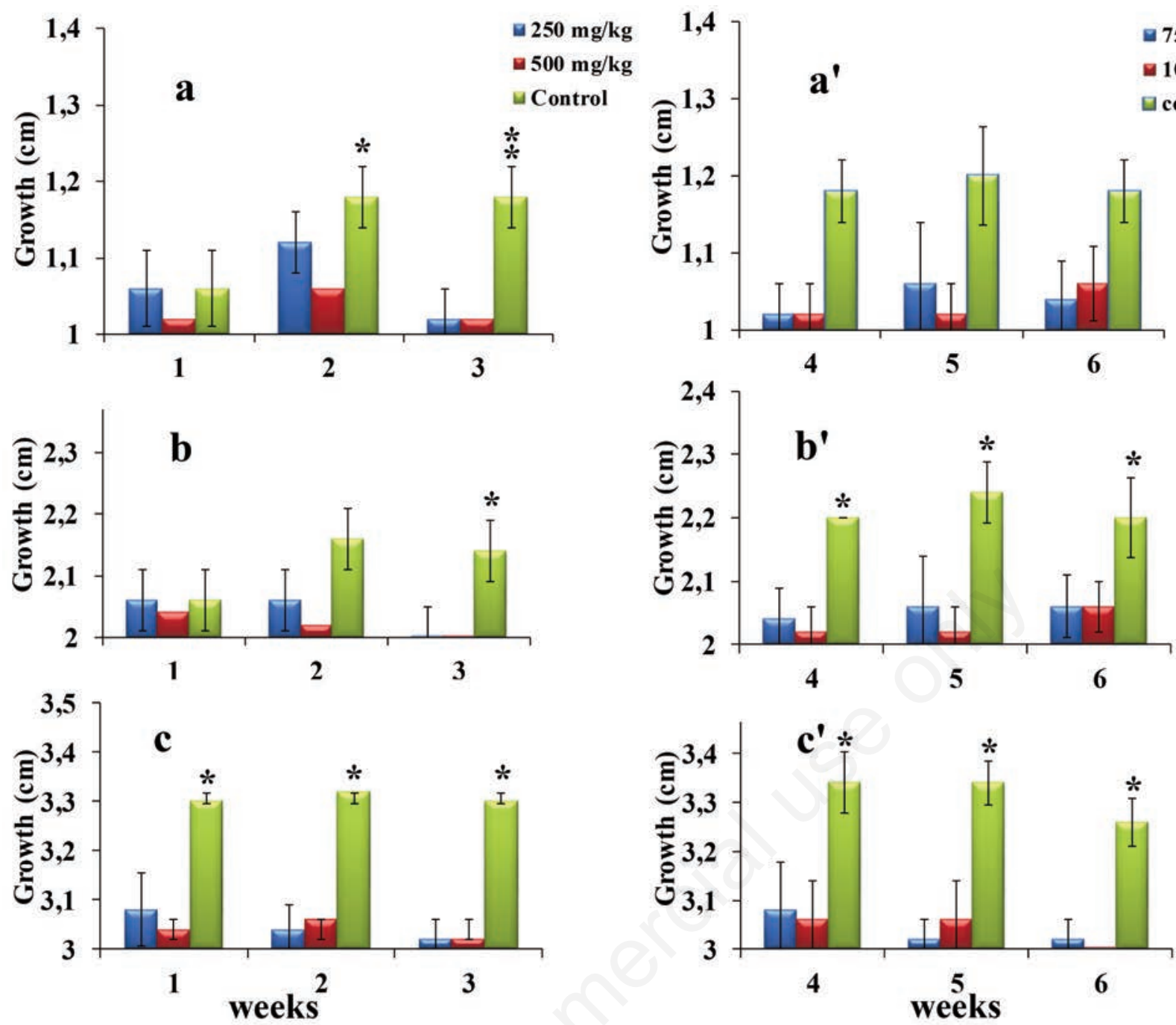

Figure 1. Evaluation of growth in the mussel Mytilus galloprovincialis of small (a, $\left.a^{\prime}\right)$, medium (b, b') and large (c, $\left.c^{\prime}\right)$ size, exposed to potassium hydrogen phthalate. $\left({ }^{*}\right)$ Meaning $\mathrm{P}<0.05$ between control and $[\mathrm{KHP}]$; $\left(^{* *}\right)$ significance $\mathrm{P}<0.05$ between control and $[\mathrm{KHPs}]$.

\section{References}

1. Bagel S, Décaudin $B$, Neuville $S$, Chopineau J, Odou P, Sautou V. phthalates in medical devices for artificial nutrition. Clin Nutr Metab 2011;25:15-23.

2. Peijnenburg W, Struijs J. Occurrence of phthalate esters in the environment of the Netherlands. Ecotoxicol Environ Safety 2006;63:204-15.

3. Merzouki M, Talib N, Sif J. Index condition and contents of some metals $(\mathrm{Cu}, \mathrm{Cd}, \mathrm{Zn}$ and $\mathrm{Hg}$ ) in the organs of the mussel Mytilus galloprovincialis from the coast of El Jadida (Morocco) in May and June 2004. Bull Sci Inst Rabat, Life Sci Sect
2009;31:21-6.

4. Sif J, Essedaoui A, Ferssiwi A Concentration du $\mathrm{Cu}, \mathrm{Zn}$ et $\mathrm{Cd}$ au niveau de la glande digestive de Mytilus galloprovincialis: rôle des métallothionéines dans la détoxification des métaux lourds. $\mathbf{J}$ Recher Océanograph 2002;27:284-7.

5. Sif J, Ferssiwi A, Talib N, Rouhi A, Merzouki M. Etude et suivi des élémentstraces au niveau de la lagune de Oualidia. Rapp Sci Progr Lagmar Maroc 2005;1:63-6.

6. Subotic U, Hannmann T, Kiss M, Brade J, Breitkopf K, Loff S. Extraction of the plasticizers diethylhexylphthalate and polyadipate from polyvinylchloride nasogastric tubes through gastric juice and feeding solution. J Pediatr Gastroenterol Nutr
2007;44:71-6.

7. Rihani L. L'effet du Di-n-Butyl Phthalate (DBP) sur les paramètres hématologiques, biochimiques et les paramètres de la reproduction chez le lapin mâle Oryctolagus Cuniculus. PhD thesis. Annaba: Univ. Sci. Badji-Mokhtar; 2014.

8. Foster PMD. Disruptions of reproductive development in male rat offspring following in utero exposure to phthalate esters. Int J Androl 2006;29:140-7.

9. Koch H M, Drexler H, Angerer J. An estimation of the daily intake of di (2-ethylhexyl) phthalate (DEHP) and other phthalates in the general population. Int J Hyg Environ Health 2003;206:77-83. 